\title{
Representasi Identitas di Medan Pasar Seni Lukis Indonesia
}

\author{
Djuli Djatiprambudi
}

Fakultas Bahasa dan Seni, Universitas Negeri Surabaya

\begin{abstract}
Abstrak. Since the middle of 1980s, Indonesian arts show striking growth, due to the dynamic appearance of painting market which was often referred as the boom of paintings. This phenomenon is triggered by the change of socialpolitical-economical conditions of Asia, which are also influencing the infrastructure and suprastructure changes of the social-politics-and economy of Indonesia. It leads to the dialectical rise of the class of economical elite in Indonesia, which is dominated by the Chinese ethnic group. This group, which was politically pressurized during New Order regime, has built a tantalous room in economy. Their involvement in the arts market can bee seen as the starting point to comprehend the economical-capitalism of Indonesian Arts. It is expected that by constructing the role of Chinese ethnic group in art market, we will obtain a complete understandings of the social history of arts in Indonesia.
\end{abstract}

Keywords: identity; boom of painting.

\section{$1 \quad$ Pengantar}

Sejak dekade 1990an terdapat dua gejala yang menonjol di dunia seni rupa Indonesia. Gejala pertama, berupa praktik pewacanaan, dan gejala kedua berupa praktik penaksiran. Gejala pertama memperlihatkan gejala internasionalisasi seni rupa dengan beragam eksplorasi estetis di dalam berbagai pameran berskala nasional maupun internasional. Gejala kedua memperlihatkan praktik pasar yang tampak begitu dominan dengan nilai perputaran kapital triliunan rupiah pertahun.

Namun, kedua gejala tersebut satu sama lain memperlihatkan gejala yang tidak saling terkait. Di satu sisi, seni rupa dipahami dalam bingkai teoritik dan ideologi seni yang menyertainya. Di sisi lain, seni rupa dipahami dalam bingkai ekonomi dan berbasis pada ideologi pasar. Tulisan ini akan menjelaskan gejala kedua tersebut dengan difokuskan pada politik representasi oleh kelas sosial yang menguasai pranata ekonomi sebagai upaya membangun identitasnya.

Pembacaan gejala ini penting mengingat selama ini sejarah seni rupa Indonesia lebih banyak dipahami melalui jalur ketokohan seorang seniman, dan seputar kekhasan estetis, ketajaman tematik, dan kekuatan teknik ungkapnya. Kajiannya lebih terarah pada persoalan intrinsik. Sementara, kajian yang mengarah pada

Received December $21^{\text {st }}$ 2006, Revised February $2^{\text {nd }} 2007$, Accepted for publication March $5^{\text {th }} 2007$. 
persoalan ekstrinsik, khususnya yang menyangkut mekanisme distribusi, trens permintaan, pranata pasar, agen dan patronase, serta ideologi di balik praktik penaksiran, hingga saat ini belum mendapat porsi kajian yang memadai.

\section{Latar Sosial: Elite Ekonomi}

Sejarah Indonesia modern pasca kejatuhan Presiden Soekarno, secara politis digantikan oleh pemerintahan baru, yang kemudian dikenal sebagai rezim Orde Baru. Sebutan Orde Baru semula hanya untuk membedakan dengan yang sebelumnya, yaitu Orde Lama di bawah Presiden Soekarno. Orde Baru dipimpin oleh Soeharto, seorang yang berlatar belakang militer dan dalam perjalanan kekuasaannya menerapkan suprastruktur politik yang menekankan

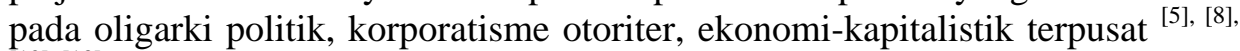
[10], [13].

Praktik kekuasaan Orde Baru yang demikian itu membutuhkan infrastruktur ekonomi dan politik yang kuat untuk menopang kekuasaannya. Dalam hal ekonomi diterapkan korporatisme otoriter dan pendekatan ekonomi-kapitalistik secara terpusat. Keadaan ini akhirnya mendorong munculnya pemusatan kekuatan ekonomi pada kelompok tertentu, yang semuanya berbasis pada kepentingan akumulasi kapital dan penguasaan jaringan ekonomi, baik dalam jalur vertikal maupun horisontal. Kelompok tertentu itu terdiri dari keluarga Soeharto, elite militer, elite birokrasi, dan elite ekonomi dari kalangan etnik Cina ${ }^{[8]}$.

Etnik Cina dimasukkan dalam jaringan ekonomi secara luas, karena secara politik pemerintahan Soeharto membatasi ruang gerak etnik ini pada bidang lain. Politik ini sama seperti terjadi pada masa kolonial, ketika itu etnik Cina diletakkan secara sosiologis sebagai golongan perantara, yang berperan dalam akses ekonomi dan perdagangan ${ }^{[11],}{ }^{[12]}$. Walaupun, kenyataannya cukup banyak dari kalangan etnik Cina yang muncul secara fenomenal di luar bidang ekonomi, misalnya di bidang olah raga, keilmuan, seni, hukum, pers, politik ${ }^{[9] \text {, }}$ [15], [16]. Namun, persepsi sebagai elite ekonomi yang menguasai mayoritas perputaran kapital dan jaringan perdagangan merupakan realitas yang tidak terelakkan.

Dalam hal politik, rezim Orde Baru menerapkan sistem partai tunggal (Golkar), walaupun pada kenyataannya ada PPP dan PDI. Namun, dua partai ini tidak mampu mengimbangi kekuatan mayoritas di tubuh Golkar yang didukung oleh tentara, birokrasi, dan massa rakyat yang dimobilisasi di bawah tekanan dan ancaman. Keadaan ini disebut sebagai oligarki politik, yaitu kekuasaan yang ditopang oleh mekanisme politik otoriter di tangan seseorang dengan kroni- 
kroninya. Dari basis politik itu, maka segala aktivitas massa rakyat di bawah kendalinya secara otoriter, termasuk di dalamnya aktivitas kesenian ${ }^{[23]}$.

Di bawah Orde Baru secara politik perkembangan kesenian (khususnya seni rupa) mendapatkan dukungan cukup memadai. Sejumlah pameran besar seperti Festival Istiqlal, pameran seni rupa Gerakan Non Blok, pameran KIAS, merupakan contoh konkret dukungan pemerintah Orde Baru dalam peristiwa tersebut. Di samping itu juga muncul infrastruktur penting yang menopang perkembangan seni rupa, seperti, Taman Ismail Marzuki, Galeri Nasional, Yayasan Seni Rupa Indonesia.

Sebaliknya, Orde Baru membatasi ruang gerak ekspresi kesenian, terutama jika bersentuhan dengan tema-tema yang bernada mengkritik pemerintah. Dalam era ini cukup banyak terjadi pencabutan ijin pameran, karena alasan-alasan stabilitas keamanan. Namun, keadaan ini bukan berarti karya-karya yang bertema kritik sosial tidak lahir di era ini. Karya cetak saring Hardi berjudul "Suhardi Presiden RI 2001" dan karya Moeljono bertema Marsinah serta karya instalasi Dadang Christanto "1001 Manusia Tanah" merupakan contoh yang menandai karya kritik sosial yang lahir di era tersebut.

Sementara itu, dalam wilayah global, terutama memasuki tahun 1980an secara simultan terjadi ledakan harga minyak dunia. Boom minyak ini kemudian melipatgandakan penerimaan devisa, karena saat itu Indonesia sebagai negara pengekspor minyak. Keadaan ini memacu pertumbuhan ekonomi sampai 7\%. Pertumbuhan ini segera memicu laju pembangunan industri dan perubahan regulasi perbankan secara mendasar. Pada saat itulah terjadi pertumbuhan di sektor riil, seperti industri manufaktur, jasa, telekomunikasi, properti, dan realestat. Bersamaan dengan gejala itu di Jakarta mulai dibangun secara besarbesar berbagai infrastruktur ekonomi, perkantoran dengan arsitektur modern.

Namun, ledakan pertumbuhan ekonomi itu hanya dirasakan oleh sekelompok elite birokrasi dan elit ekonomi yang secara dominan berasal dari etnik Cina. Elit ekonomi ini telah lama memegang kunci jaringan ekonomi dan perdagangan sejak masa kolonial Belanda. Elite ekonomi ini kemudian muncul sebagai kelas berkuasa, yaitu kelas yang menguasi infrastruktur ekonomi, yang kemudian dikenal sebagai kongklomerat. Dari sinilah kemudian timbul kekuatan ekonomi yang secara mayoritas dikuasai oleh etnik Cina, yang menguasai jaringan ekonomi mulai dari atas ke bawah ${ }^{[17], \text { [24]. }}$.

Penguasaan kapital dan jaringan ekonomi tersebut pada saat terjadi krisis ekonomi 1997, yang ditandai ambruknya sejumlah bank swasta, apresiasi rupiah terhadap dollar anjlok, terhentinya roda industri di sektor riel yang menimbulkan gelombang pengangguran di perkotaan, akhirnya memicu gejala 
pengalihan kapital ke luar negeri (capital flight) dan pengalihan investasi di sektor lain.

Bersamaan dengan krisis tersebut, dunia seni rupa yang saat itu sedang mengalami isu boom lukisan sejak pertengahan 1980an di sejumlah sesi lelang dunia di Christie's dan Sotheby's, dan isu sejumlah pengusaha raksasa Jepang sebagai pemecah rekor lelang karya-karya master dunia, menjadi titik penting dalam konteks pengalihan investasi sejumlah elite ekonomi ke sektor seni lukis.

Seni lukis tiba-tiba dipercaya sebagai lahan investasi, yang dapat mendatangkan keuntungan besar dalam waktu singkat. Dari sini kemudian secara simultan muncul komunitas bisnis seni lukis, yang sebagian besar pelakunya berasal dari kalangan elit ekonomi etnik Cina. Dari sini terlihat adanya perubahan paradigma dari seni lukis dipandang sebagai benda seni yang memiliki seperangkat nilai estetis-filosofis, bergeser menjadi sesuatu benda komoditas yang patuh pada hukum perdagangan.

Komunitas bisnis seni lukis yang orientasinya lebih memandang seni lukis sebagai komoditas, lebih didasarkan pada perspektif bisnis atau paradigma ekonomi dalam memandang suatu karya seni. Karena itu, untuk membangun jaringan bisnis seni lukis tersebut, secara simultan juga dibangun infrastrukur pendukungnya, yaitu, galeri, art dealer, art broker, lembaga lelang, media, yang kemudian infrastruktur ini merambah secara luas di dalam pertumbuhan medan sosial seni hingga sekarang.

\section{Etnik Cina: Seni Lukis dan Relasi Sosial}

Dari posisi etnik Cina yang merupakan representasi elite ekonomi di Indonesia seperti dijelaskan di atas, maka muncul persepsi mendasar bahwa hampir semua sumber daya ekonomi berada dalam kekuasaannya. Ini bisa terjadi, karena adanya kebijakkan pemerintah yang sengaja memposisikan etnik Cina hanya dalam bidang ekonomi. Akibatnya muncul persepsi steriotipe bahwa etnik Cina sebagai "economic animal", yaitu orang yang hanya mencari uang dan untung. Posisi ini, ketika Orde Baru tumbang, sering dikaitkan sebagai salah satu faktor penyebabnya. Ambruknya pemerintahan Soeharto menurut Winters [23] juga dapat dijelaskan melalui sepak-terjang kroni-kroninya yang berasal dari kalangan elite ekonomi tersebut.

Etnik Cina menjadi etnik terdepan dalam penguasaan jaringan ekonomiperdagangan, selain disebabkan fasilitas politik Orde Baru juga secara mendasar disebabkan budaya dagang etnik Cina. Budaya ini diwarnai oleh semangat kapitalistis yang didasarkan pada kekeluargaan: pemupukan modal dan kekayaan dari keluarga, oleh keluarga dan untuk kepentingan dan keamanan 
keluarga. Budaya ini dipengaruhi oleh nilai Konfusianisme, yang menyatakan bahwa tujuan hidup individu adalah menciptakan keutuhan, keharmonisan dan keamanan keluarga. Ajaran moral tersebut dianggap sebagai pedoman efisiensi ekonomi [1], [2], [3], [22].

Posisi yang steriotipe itu sebenarnya telah mulai dibongkar seiring dengan perkembangan sosial politik pasca Orde Baru. Gejala ini memperlihatkan bahwa etnik Cina ingin memainkan peran-peran sosial-budaya secara luas. Keinginan itu pada dataran lebih luas sebagai relasi dari penguasaan ekonomi di satu pihak dan representasi identitas kelas elite ekonomi di pihak lain. Gejala ini dalam konteks seni rupa dapat dilihat dari merebaknya etnik Cina dalam dunia pasar seni lukis, yang mulai semarak sejak akhir 1980an.

Kalaupun etnik Cina seperti tiba-tiba masuk di medan pasar seni lukis, gejala ini sebenarnya juga didasarkan pada tradisi di kalangan mereka sendiri yang telah lama memiliki budaya mengoleksi karya seni sebagai bagian pengukuhan simbol status sosial. Keberhasilan ekonomi etnik Cina pada masa lalu, misalnya, dapat dilihat dari seberapa besar koleksi porselin antik dan lukisan klasik Cina yang dimilikinya, atau seberapa banyak ukiran-ukiran rumit terdapat di rumahnya (Lihat: Ong Hok Ham, 2005).

Dalam konstruk pasar, kalangan etnik Cina memperlihatkan fenomena tersendiri. Hal ini tampak jelas pada lapis-lapis konstruk pasar, mulai dari lembaga lelang, kolektor, galeri, art dealer, broker, kurator, hingga penerbitan, hampir semua didominasi oleh etnik Cina. Atas gejala ini, akhirnya timbul persepsi kuat bahwa etnik Cina merupakan etnik terbesar dalam kapasitasnya sebagai 'pemain tunggal' di dalam pasar seni rupa. Kelompok ini kemudian membangun diri menjadi semacam agen-agen, maesinas atau patronase dalam dunia seni rupa.

Kehadiran etnik Cina dalam dunia seni rupa Indonesia, sebenarnya telah cukup lama. Pada era Soekarno, misalnya, keterlibatan sekelompok orang keturunan etnik Cina dalam dunia seni rupa tampak menonjol. Terbukti pada era itu dua orang pelukis keturunan Cina, Lee Man Fong dan Lim Wa-Shim, diangkat sebagai pelukis Istana. Di luar tembok istana bahkan berkembang jaringan kolektor yang dapat berhubungan langsung dengan Soekarno, yang kala itu sedang bersemangat mengoleksi lukisan atau karya seni lainnya, termasuk porselin Cina. Dari jaringan itu, Soekarno banyak mendapatkan lukisan, baik lukisan bergaya Cina klasik maupun lukisan modern karya sejumlah pelukis Indonesia yang terkenal saat itu. 


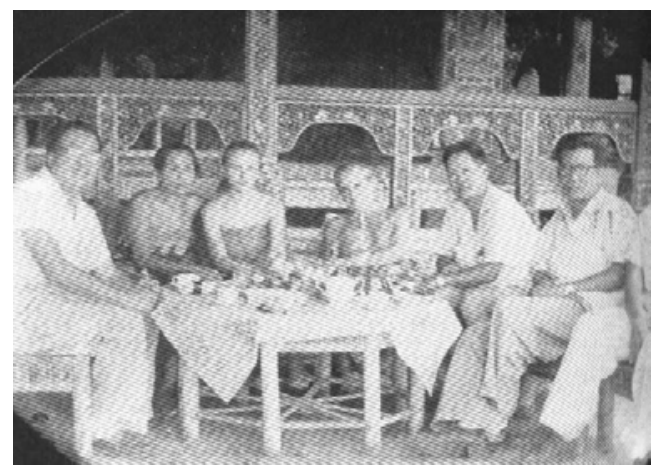

Gambar 1 Lee Man Fong (kedua dari kiri) Le Meyeur, Huang Tu Fang, Ni Polok dan Siauw Tik Kwie (sumber : 'Visual Art’,Okt/Nov 2006).

Realitas di atas terus berlangsung hingga pada pemerintahan Orde Baru, yaitu ketika titik-titik pertumbuhan ekonomi dikuasai oleh etnik Cina. Mereka dengan jaringan bisnisnya menguasi infrastruktur, bahkan dalam banyak hal, karena pengaruh penguasaan kalital, mereka dapat mempengaruhi suprastruktur negara. Dua pengaruh besar inilah, yang pada gilirannya memunculkan kelompok elit ekonomi, yang secara politis ikut mempengaruhi arah kebijakan ekonomi, tetapi juga berdampak pada munculnya tegangan-tegangan sosial. Tegangan sosial itu sebenarnya merupakan akumulasi dari berbagai prasangka terhadap etnik Cina yang telah terbentuk sejak lama, bahkan sejak masa kolonial.

Memang, dalam beberapa kasus, tegangan sosial itu menjurus pada diskriminasi etnik Cina, yang pada akhirnya mengakibatkan tindakan kontra-produktif. Tegangan itu di satu pihak (berhubungan dengan kepentingan ekonomi) etnik Cina dapat hadir secara fenomenal, tetapi di pihak lain (berhubungan dengan kepentingan non-ekonomi) etnik Cina dikaburkan kehadirannya. Akibatnya, sekali lagi, etnik Cina sering mendapatkan citra yang hampir dipahami secara steriotipe sebagai binatang ekonomi, yang serakah, eksploitatif, bahkan manipulatif.

Persoalan ini secara dilematis menurut Yoshihara Kunio (1990) sebenarnya salah satu rentetan dari pertumbuhan kapitalisme di Asia Tenggara yang dikatakan sebagai kapitalisme ersatz. Kapitalisme ini dikatakan sebagai kapitalisme subtitusi yang lebih inferior, jika dibandingkan kapitalisme yang menggejala di Eropa pada abad ke-19. Kapitalisme yang berkembang di Eropa berhasil membawa kawasan ini keluar dari sistem feodal dan masuk ke sistem kapitalisme industri sehingga melahirkan kemajuan teknologi dan ekonomi yang luar biasa. Kapitalisme ini disebutnya sebagai kapitalisme dinamis. 
Selain kawasan Eropa, kapitalisme dinamis juga berkembang di Amerika Serikat, Jepang, Taiwan, Korea Selatan, Singapura, Hongkong. Kapitalisme yang seperti ini menurut Kunio tidak berkembang di Asia Tenggara. Yang ada di sini adalah kapitalisme ersatz. Mengapa kawasan Asia Tenggera terbentuk kapitalisme ersatz?

Pertama, di Asia Tenggara campur tangan pemerintah terlalu banyak sehingga mengganggu prinsip persaingan bebas dan membuat kapitalisme menjadi tidak dinamis. Ini juga menimbulkan tumbuhnya pencari rente di kalangan birokrat pemerintah, sehingga wiraswastawan sesunggugnya tidak dapat berkembang. Kemudian dia juga menimbulkan kekuatan ekonomi pengusaha-pengusaha keturunan Cina, yang melalui koneksinya dengan para birokrat negara, berhasil memperoleh fasilitas-fasilitas khusus bagi usahanya.

Kedua, Kapitalisme di Asia Tenggara tidak didasarkan perkembangan teknologi yang memadai. Akibatnya, tidak terjadi industrialisasi yang mandiri. Kapitalisme di Asia Tenggara kebanyakan hanya bergerak di bidang jasa. Kalaupun bergerak di bidang industri, dia hanya berperan sebagai kapitalisme komprador (bertindak sebagai agen industri manufaktur asing di negerinya

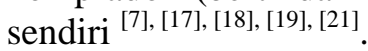

Praktik ekonomi yang mengandalkan campur tangan kekuasaan birokrasi pemerintah dan politik yang berlebihan, pada akhirnya mengakibatkan ekonomi biaya tinggi, karena para pengusaha harus menyediakan dana untuk memperlancar usahanya. Dari sini maka timbul saling ketergantungan antara keduanya. Para elite penguasa perlu biaya besar untuk mempertahankan kekuasaannya, dengan demikian perlu membangun kerjasama dengan elite pengusaha. Sementara, para pengusaha perlu mendapatkan perlindungan politik dalam memainkan model ekonomi yang mendominasi dari hulu ke hilir, maka diperlukan kedekatan mereka dengan elite penguasa guna membangun kerajaan bisnisnya.

Sementara itu, dalam kasus Malaysia dan Indonesia, misalnya, para elite penguasa dipegang oleh masyarakat pribumi, sedangkan elite pengusaha dipegang oleh masyarakat etnik Cina. Para elite penguasa kebanyakan berasal dari etnik mayoritas, sementara para elite pengusaha berasal dari etnik minoritas. Di satu pihak (mayoritas) menguasai jaringan birokrasi dan kebijakan politik nasional, sementara di pihal lain (minoritas) mengendalikan perputaran roda ekonomi dengan jejaring kapitalnya yang sangat besar.

Dari perspektif ini keduanya jelas memiliki dilema. Di Malaysia, misalnya, kelompok mayoritas (Melayu) seperti yang ditulis Mahathir Mohamad juga mengalami dilema. Apalagi polulasi etnik Cina di Malaysia cukup besar (sekitar 
33,36 \% menurut sensus tahun 1980). Artinya, etnik Cina merupakan kekuatan ekonomi yang amat besar dalam konteks pertumbuhan ekonomi di Malaysia secara menyeluruh. Ini terbukti sebagaian besar industri manufaktur yang mengendalikan banyak tenaga kerja dan modal dikuasai elite pengusaha etnik Cina. Gejala ini ditangkap sebagai ancaman serius bagi masyarakat pribumi (Melayu).

Kelompok minoritas (etnik Cina) pada kenyataannya menghadapi dilema yang tak kalah rumitnya. Dilema itu pertama-tama datang dari persoalan kecurigaan kelompok minoritas akan peran mereka yang terlampau besar dalam ekonomi. Di samping itu, kelompok minoritas sering menghadapi perlakuan yang tidak adil, terutama menyangkut kesukuan, keturunan, hak dan kewajiban warga negara, perlindungan hukum, dan peran sosial di masyarakat. Justru karena perlakuan-perlakuan yang dirasakan tidak adil itu, kelompok minoritas hanya ada satu kemungkinan untuk bertahan hidup, yaitu dengan melakukan aktivitas ekonomi di berbagai sektor. Pembatasan di berbagai hal, pada kenyataannya memperbesar pada hal lain, yaitu dominasi ekonomi.

Kenyataan dilematis ini kemudian secara sosial budaya antara lain diterobos melalui berbagai aktivitas di segala sektor medan sosial seni rupa. Pilihan di seni rupa ini selain dilatarbelakangi oleh kehendak dasar untuk membangun konstruk baru dalam ranah sosial budaya dalam konteks membangun identitas secara lebih luas (tidak steriotipe), ia juga dilatarbelakangi oleh peristiwa global yang terjadi di kawasan Asia Pasifik, yaitu adanya boom seni lukis dan perubahan sosial yang menyertainya.

\section{$4 \quad$ Lukisan sebagai Investasi}

Munculnya persepsi tentang seni lukis dalam konteks komoditas dan investasi secara sosial historis dapat ditelusuri pada gejala global yang terjadi pada pertengahan dekade 80-an, di mana sejumlah konglomerat Jepang memborong karya-karya master seni lukis dunia, antara lain karya Monet, van Gogh, Cezanne, Degas dari rumah lelang Christie's dan Sotheby's. Konglomerat ini berani memborong karya master dunia, tidak lain akibat booming ekonomi Jepang dan juga ada semacam "desain besar" agar terjadi pergeseran pusat seni rupa kontemporer dunia berada di Jepang.

Gejala ini bagai 'efek domino', secara cepat berdampak pada dinamika seni rupa terutama di kawasan Asia Pasifik. Gejala ini meluas sampai ke Indonesia bertepatan dengan sejumlah elit ekonomi yang berasal dari etnik Cina kebingungan menginvestasikan uangnya ketika terjadi puncak pertumbuhan ekonomi Indonesia, pertengahan 1980an, hingga munculnya krisis ekonomi, akhir 1990an. Para elit ekonomi tersebut tiba-tiba beralih sebagai pemburu 
lukisan yang dianggap kelas master, dan menjualnya kembali di arena pasar yang saat itu tumbuh luar biasa. Pertumbuhan ini juga dipicu dibukanya dua rumah lelang karya seni di Singapura dan Hongkong. Gejala ini memperlihatkan bahwa kawasan Asia Pasifik telah menjadi medan pasar seni seiring dengan tumbuhnya kelas menengah dan elit serta konglomerat yang sedang mengalami status 'perang simbol'. Kelas-kelas sosial ini muncul melalui keinginan mengoleksi yang kemudian berubah menjadi keinginan berinvestasi.

Sementara itu, secara sosial-ekonomi, di Indonesia sedang terjadi perubahan yang cukup bermakna. Memasuki dekade 1990an, pemerintah Orde Baru yang mulai melemah, yang akhirnya secara simbolik Soeharto sebagai 'ikon' Orde Baru mengundurkan diri sebagai presiden pada Mei 1998. Mundurnya Soeharto sebenarnya sebagai akumulasi krisis multidimensional yang sudah lama terjadi. Praktik pemerintahan yang sentralistik-otoriter pada akhirnya hanya melegitimasi kekuatan-kekuatan tertentu yang menguasai pranata sosialekonomi masyarakat. Maka, akibatnya pada saat krisis ekonomi dunia berlangsung, Indonesia menjadi korban dan mendapat kesulitan untuk bangkit lagi. Era reformasi yang diharapkan mampu menata kembali kekacauan di berbagai sektor, kenyataannya belum ada tanda-tanda ke arah perbaikan, secara praktis Indonesia saat ini sebenarnya dalam kondisi tidak menentu, termasuk dalam dunia seni rupanya.

Namun, justru dalam kondisi tidak menentu itulah para elit ekonomi yang masih gamang atau ketakutan menginvestasikan modalnya dalam dunia perdagangan, properti, jasa dan industri, memanfaatkannya itu dalam dunia seni lukis yang dianggap aman dan diproyeksikan memiliki keuntungan yang berlipat ganda. Pada saat itulah lukisan diformat menjadi barang dagangan (komoditas yang diperjual-belikan secara bebas). Akhirnya, era 1990an dunia seni rupa diwarnai secara dominan oleh perilaku komodifikasi lukisan secara besar-besaran. Kondisi demikian terus berlangsung sampai hari ini.

Pada era ini puluhan galeri tumbuh menjamur di berbagai kota, khususnya Jakarta dan Bali. Belakangan menyusul di Yogyakarta, Bandung, Semarang dan Surabaya. Galeri-galeri ini didirikan sebagian besar didorong oleh motif-motif komodifikasi lukisan. Galeri tidak ubahnya semacam pusat-pusat mode atau pusat-pusat selera. Tidak hanya hanya geleri, tiba-tiba secara akumulatif muncul lembaga lelang, art dealer, broker, kolektor, yang kehadirannya mampu meningkatkan dinamika pasar lukisan.

Dengan memperhatikan kondisi tersebut, dalam waktu kurang lebih 20 tahun terakhir, dunia seni rupa Indonesia berkembang dalam format yang tidak seimbang. Karya seni lukis diperebutkan dan seakan-akan menjadi primadona, sedangkan karya seni lainnya hampir dapat dikatakan kurang tersentuh oleh 
komodifikasi tersebut. Karena itu, secara sosial sejumlah pelukis tiba-tiba tumbuh menjadi "seniman borjuis".

Sekalipun dunia pasar yang tampak mengacaukan pranata seni rupa, pada kenyataannya tidak semuanya berdampak kurang baik. Kolektor dan pemilik galeri yang sering dicurigai mengeksploitasi seniman, ternyata dalam banyak hal mereka mensponsori berbagai event pameran penting. Barangkali kalau tidak ada orang semacam Tjiean An Djie, CP Open Biennale tidak pernah ada di Indonesia. Demikian juga jika tidak ada Teguh Wibisono, mungkin sampai sekarang tidak ada majalah Visual Arts. Selain itu masih banyak kolektor yang secara pribadi membiayai sejumlah seniman Indonesia untuk ikut tampil dalam forum pameran seni rupa berskala internasional.

Di samping menjadi sponsorship dalam sejumlah pameran, mereka dalam 10 tahun belakangan mulai merambah dalam penerbitan buku-buku seni rupa. Sepanjang tahun 2003, misalnya, sejumlah kolektor bersekutu membuat buku monografi sejumlah pelukis, antara lain; Nashar, Koempoel, Lee Man-fong, Affandi, Sudarso, Awiki, Fadjar Sidik, Made Sukadana, Arie Smit, Lim Wasim, Dede Eri Supria, Made Wianta, Srihadi Soedarsono, S. Soedjojono, dsb. Sekalipun buku-buku tersebut dicurigai oleh sejumlah kalangan hanya sebagai strategi untuk menembus pasar secara lebih luas, namun buku-buku tersebut bagaimanapun tetap penting dalam konteks minimnya publikasi seni rupa di Indonersia.

\section{$5 \quad$ Representasi Identitas}

Peran dan posisi etnik Cina yang beroperasi di dunia pasar seni lukis tersebut pada dataran lebih luas memperlihatkan representasi identitas yang hendak dibangun. Representasi identitas ini terkait dengan ideologi, kuasa ekonomi, kultur dagang, tradisi mengoleksi, dan posisi steriotipe yang telah berlangsung lama.

Istilah representasi memiliki dua pengertian. Pertama, representasi sebagai sebuah "proses sosial" dari representing. Kedua, representasi sebagai "produk" dari proses sosial representing. Istilah yang pertama merujuk pada proses, sedangkan yang kedua merupakan produk dari pembuatan tanda yang mengacu pada suatu makna. Proses representasi sendiri melibatkan tiga elemen. Pertama, sesuatu yang direpresentasikan, disebut objek; kedua, representasi itu sendiri, yang disebut sebagai tanda; dan ketiga adalah seperangkat aturan yang menentukan hubungan tanda dengan pokok persoalan, disebut coding..

Representasi berarti menggunakan bahasa untuk mengatakan sesuatu yang penuh arti atau menggambarkan dunia yang penuh arti kepada orang lain. 
Makna didekonstruksi oleh sistem representasi dan diproduksi melalui sistem bahasa yang fenomenanya tidak hanya disampaikan lewat ungkapan verbal, tetapi juga visual. Sistem representasi tidak tersusun atas konsep pribadi, tetapi dengan cara-cara pengorganisasian, penyusunan, dan pengklasifikasian konsep dan berbagai kompleksitas hubungan di antara mereka.

Dengan merujuk konsep tersebut, tindakan etnik Cina dalam konteks peran dan posisinya di medan pasar seni lukis, memperlihatkan proses representasi. Seni lukis dalam konteks ini dijadikan tanda yang dipercaya dapat memproduksi makna representasi dalam dimensi sosial-budaya secara luas. Seni lukis dalam arti tertentu juga dijadikan tanda untuk membangun simbol sosial, yang terkait dengan kelas, status, kuasa, dan juga resistensi. Dalam kaitan dengan kompleksitas sosial-budaya di Indonesia, representasi identitas etnik melalui medan pasar seni lukis secara langsung berfungsi ekonomis, tapi juga berfungsi kultural. Artinya, kegiatan di medan pasar seni lukis beserta ideologi dan strateginya, pada sisi ini memperlihatkan upaya etnik Cina membongkar persepsi steriotipe yang dirasakan lebih bersifat prasangka dan politis. Medan pasar dengan demikian merupakan ruang sosio-kultural etnik Cina dalam upaya membangun representasi identitas sebagai etnik minoritas.

\section{Daftar Pustaka}

[1] Charlie, Lie. 2006. Resep Kaya Ala Tionghoa: Financial Strategy. Bandung: TriExs Media.

[2] 2005. Sukses Dalam Bisnis: Pentingnya Perencanaan. Bandung: Nexx Media, Inc.

[3] . 2004. Resep Kaya Ala Tionghoa: Kiat Jitu Sukses secara Finansial. Bandung: Nexx Media, Inc.

[4] Coppel, Charles A. 1994. Tionghoa Indonesia dalam Krisis, (Penerjemah Tim Pustaka Sinar Harapan). Jakarta: Sinar Harapan, cet. ke-2.

[5] Emmerson, Donald, K. 2001. Indonesia Beyond Soeharto: Negara, Ekonomi, Masyarakat, Transisi, (Penerjemah Perikles Kattopo). Jakarta: PT Gramedia Pustaka Utama, cet. ke-2.

[6] Hamilton, Gary. 1996. Menguak Jaringan Bisnis Cina di Asia Timur dan Tenggara, (Penerjemah Alexander Irwan). Jakarta: PT Gramedia Pustaka Utama.

[7] Hefner, Robert, W. (Ed.). 2000. Budaya Pasar: Masyarakat dan Moralitas dalam Kapitalisme Asia Baru, (Penerjemah T. Iskandar Ali). Jakarta: LP3ES.

[8] Hiariej, Eric. 2005. Materialisme Sejarah Kejatuhan Soeharto: Pertumbuhan dan Kebangkrutan Kapitalisme Orde Baru, (Penerjemah Bambang MBK). Yogyakarta: IRE Press. 
[9] Jahja, Junus, H. 2002. Peranakan Idealis: Dari Lie Eng Hok sampai Teguh Karya. Jakarta: Kepustakaan Populer Gramedia.

[10] Kunio, Yoshihara. 1991. Kapitalisme Semu Asia Tenggara, (Penerjemah A. Setiawan Abadi). Jakarta: LP3ES, cet. ke-2.

[11] Lohanda, Mona. 2001. The Kapitan Cina of Batavia 1837-1942: A History of Chinese Establishment in Colonial Society. Jakarta: Djambatan, cet. ke-2.

[12] 2002. Growing Pains: The Chinese and The Dutch in Colonial Java, 1890 - 1942. Jakarta: Yayasan Cipta Loka Caraka.

[13] Ricklefs, M.C. 2005. Sejarah Indonesia Modern 1200-2004. Jakarta: PT Serambi Ilmu Semesta.

[14] Setiono, Benny, G. 2002. Tionghoa dalam Pusaran Politik. Jakarta: ELKASA.

[15] Sidharta, Myra, (Ed). 1989. 100 Tahun Kwee Tek Hoay: Dari Penjaja Tekstil sampai ke Pendekar Pena. Jakarta: Pustaka Sinar Harapan.

[16] 2004. Biografi Delapan Penulis Peranakan: Dari Penjaja Tekstil sampai Superwoman. Jakarta: Kepustakaan Populer Grame

[17] Suryadinata, Leo. 1984. Dilema Minoritas Tionghoa, (Penerjemah Wilandari Supardan). Jakarta: Grafiti Pers.

[18] 1999. Etnis Tionghoa dan Pembangunan Bangsa. Jakarta: LP3ES.

[19] 2002. Negara dan Etnis Tionghoa: Kasus Indonesia. Jakarta: LP3ES.

[20] (Ed.). 2005. Pemikiran Politik Etnis Tionghoa Indonesia 1900-2002, (Penerjemah Nur Iman Subono). Jakarta: LP3ES.

[21] Vey, Ruth Mc. (Ed.). 1998. Kaum Kapitalis Asia Tenggara, (Penerjemah A. Setiawan Abadi). Jakarta: Yayasan Obor Indonesia.

[22] Wibowo, I. (Ed.). 2001. Harga yang Harus Dibayar; Sketsa Pergulatan Etnis Cina di Indonesia. Jakarta: Gramedia Pustaka Utama, cet. ke-2.

[23] Winters, Jeffrey, A. 1999. Dosa-dosa Politik Orde Baru, (Penerjemah Aditya Priyawardhana, dkk.). Jakarta: Djambatan

[24] Yang, Twang Peck. 2005. Elite Bisnis Cina di Indonesia dan Masa Transisi Kemerdekaan 1940-1950, (Penerjemah Apri Danarto). Jogjakarta: Niagara. 